\title{
Resolution of a Membrane-associated Thiosulphate-oxidizing Complex of Thiobacillus novellus
}

\author{
By JAE KEY OH AND ISAMU SUZUKI \\ Department of Microbiology, University of Manitoba, \\ Winnipeg, Manitoba, Canada $R_{3} T_{2} N_{2}$
}

(Received 6 July 1976; revised I December 1976)

\begin{abstract}
SUMMARY
The thiosulphate-oxidizing system of Thiobacillus novellus was destroyed by treatment with proteolytic enzymes, phospholipase A, sodium deoxycholate and lysolecithin, indicating essential roles for phospholipids and proteins in the membrane complex. The complex was partially resolved with trypsin and sodium deoxycholate into component enzymes involved in the oxidation of thiosulphate to sulphate: thiosulphate-cleaving enzyme (rhodanese; EC 2.8.I.I), sulphuroxidizing enzyme (EC I.13.II.I8), sulphite:cytochrome $c$ oxidoreductase (EC I.8.2.1) and cytochrome $c$ oxidase (EC I .9.3. I). All attempts to reconstitute the thiosulphate-oxidizing system from these component enzymes were unsuccessful. A possible mechanism for thiosulphate oxidation by the complex is discussed.
\end{abstract}

\section{INTRODUCTION}

We have reported the isolation from Thiobacillus novellus of a membrane-associated complex capable of oxidizing thiosulphate completely to sulphate (Oh \& Suzuki, I977). The isolated membrane vesicles oxidized thiosulphate, but not sulphur and sulphite which are the presumed intermediates of thiosulphate oxidation (Suzuki, 1974). The sulphur-oxidizing enzyme (sulphur:oxygen oxidoreductase, EC I.I3.II.I8) and sulphite:cytochrome $c$ oxidoreductase (sulphite:ferricytochrome $c$ oxidoreductase, EC I .8.2. I) were not detected in the membrane vesicles, although rhodanese (thiosulphate:cyanide sulphurtransferase, EC 2.8 . I . I) activity was shown. Since these enzymes are present in the crude extract of T. novellus (Charles \& Suzuki, 1966) and are presumably responsible for the oxidation of thiosulphate in the organism, they may be present in the membrane vesicles as components of the thiosulphate-oxidizing enzyme complex, but not as free enzymes exposed on the vesicle surface.

This paper reports the effects of proteolytic enzymes, phospholipases, detergents and lysolecithin on the thiosulphate-oxidizing system, which we have studied in an attempt to resolve the membrane-associated complex into individual component enzymes.

\section{METHODS}

Culture and harvesting of Thiobacillus novellus strain ATCC8093, preparation of crude extracts and membrane vesicles, and assay methods for enzymes have been described previously (Oh \& Suzuki, 1977).

Treatment with proteolvtic enzymes. Unless otherwise indicated the following standard conditions were used. Whole cells ( $2 \mathrm{mg}$ wet wt $\mathrm{ml}^{-1}$ ), crude extracts or membrane vesicles 
(both $\mathrm{I} .5 \mathrm{mg}$ protein $\mathrm{ml}^{-1}$ ) in $\mathrm{O} \cdot \mathrm{I} \mathrm{M}$-Tris acetate/0.02 $\mathrm{M}$-potassium phosphate buffer, $\mathrm{pH} 7.5$, containing $10 \mathrm{mM}^{-\mathrm{MgSO}_{4}}$, were incubated at $25{ }^{\circ} \mathrm{C}$ with bovine pancreatic trypsin (I mg $\mathrm{ml}^{-1}$ ). After incubation (normally for $30 \mathrm{~min}$ ), the proteolytic action of trypsin was stopped by adding soybean trypsin inhibitor $(2$ to $3 \mathrm{mg}$ ) in the same buffer. The treated mixtures were centrifuged at $2000 \mathrm{~g}$ for $20 \mathrm{~min}$ (whole cells) or $105000 \mathrm{~g}$ for $\mathrm{I} 20 \mathrm{~min}$ (extracts and vesicles). Protein and various oxidizing activities were determined in the pellet and supernatant fractions or in the mixtures before centrifugation as indicated in each experiment. To measure the activities, the pellets were suspended in $0.1 \mathrm{M}$-Tris acetate/0.02 M-potassium phosphate, $\mathrm{pH} 7 \cdot 5$, containing trypsin inhibitor $\left(\mathrm{I} \mathrm{mg} \mathrm{ml}^{-1}\right)$.

Pronase treatment was carried out similarly except that pronase was used at 100 or $200 \mu \mathrm{g}$ $\mathrm{ml}^{-1}$ ( 4.5 or 9 proteolytic kilo-units) and the incubation time was normally $5 \mathrm{~min}$. No inhibitor was used to stop the reaction.

Treatment with lipase, phospholipases and lysozyme. Intact cells ( $2 \mathrm{mg}$ wet $\mathrm{wt} \mathrm{ml}^{-1}$ ) or membrane vesicles ( $\mathrm{I} \cdot 55 \mathrm{mg}$ protein $\mathrm{ml}^{-1}$ ) were pre-incubated with various enzymes at $25^{\circ} \mathrm{C}$ for $20 \mathrm{~min}$ in $0.1 \mathrm{M}$-Tris acetate/0.02 M-potassium phosphate buffer, $\mathrm{pH} \mathrm{7.5}$, containing $2 \mathrm{mM}-$ $\mathrm{CaCl}_{2}$. Lipase and phospholipase $\mathrm{A}$ were dissolved in the same buffer at I $\mathrm{mg} \mathrm{ml}^{-1}$, phospholipases $\mathrm{C}$ and $\mathrm{D}$ were dissolved in the buffer at $5 \mathrm{mg} \mathrm{ml}^{-1}$, and lysozyme was dissolved in water at $100 \mathrm{mg} \mathrm{ml}^{-1}$. These enzymes were used without further purification; their concentrations were varied as required. After incubation, the thiosulphate-oxidizing activity was assayed.

Treatment with ionic and non-ionic detergents. Cell-free preparations ( $1.5 \mathrm{mg}$ protein $\mathrm{ml}^{-1}$ ) in $0 . \mathrm{I} \mathrm{M}$-Tris acetate/0.02 $\mathrm{M}$-potassium phosphate buffer, $\mathrm{pH} 7.5$, were incubated with various detergents at $4{ }^{\circ} \mathrm{C}$. All detergents were added slowly and the mixtures were stirred gently. After $30 \mathrm{~min}$, half of the mixture was immediately assayed for the thiosulphateoxidizing activity and the other half was dialysed against the same buffer for $3 \mathrm{~h}$ at $4{ }^{\circ} \mathrm{C}$ before assay.

Treatment with lysolecithin. Lysolecithin solution $\left(30 \mathrm{mg} \mathrm{ml}^{-1}\right.$ in water) was added to the crude cell-free extract $\left(24 \mathrm{mg}\right.$ protein $\mathrm{ml}^{-1}$ ) at a ratio of $0.8 \mathrm{ml}$ per $\mathrm{ml}$ of extract. The mixture was then incubated at $25^{\circ} \mathrm{C}$ and the thiosulphate-oxidizing activity was assayed in $0.2 \mathrm{ml}$ samples removed from the reaction mixture at various times.

Preparation of ferrocytochrome $c$-550. Ferrocytochrome $c$ was prepared from ferricytochrome $c$ (horse heart, type III) as described previously (Oh \& Suzuki, 1977).

Protein was determined by the method of Lowry et al. (195I), using crystalline bovine serum albumin as the standard.

Chemicals. Catalase (liver), cytochrome $c$ (horse heart, type III), bovine serum albumin, lysozyme (egg white), phospholipases A, C and D, lipase, trypsin (bovine pancreatic), soybean trypsin inhibitor, lysolecithin (egg lecithin), spermine, spermidine, ATP, ADP, AMP, cyclic AMP, FAD and FMN were purchased from Sigma; pronase (B grade) from Calbiochem; sodium deoxycholate from Fisher Scientific Co., Fairlawn, New Jersey, U.S.A.; Triton X-100, Tween 80 and precipitated sulphur powder from J. T. Baker Chemical Co., New Jersey, U.S.A.; and Sephadex G-25 from Pharmacia. The colloidal sulphur, used as substrate for sulphur-oxidizing enzyme, was prepared by the method of Suzuki (1965). Other chemicals were of analytical grade. 


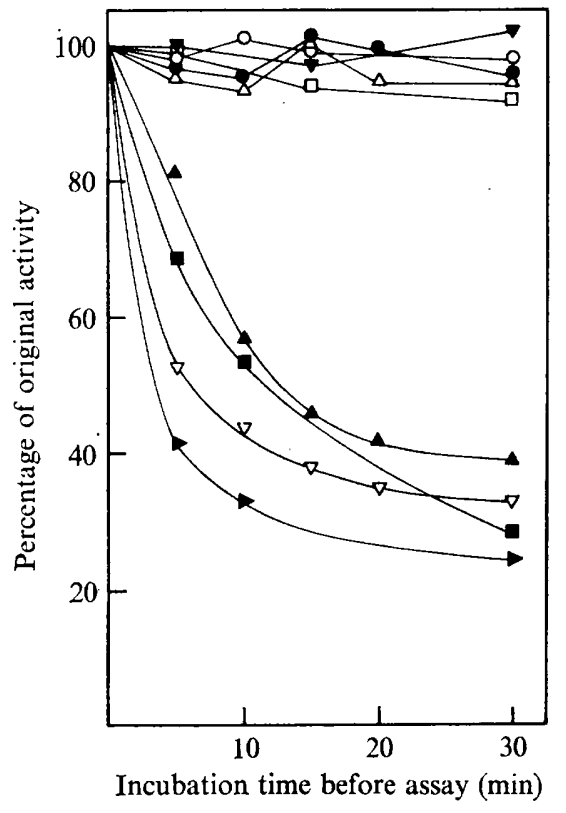

Fig. I

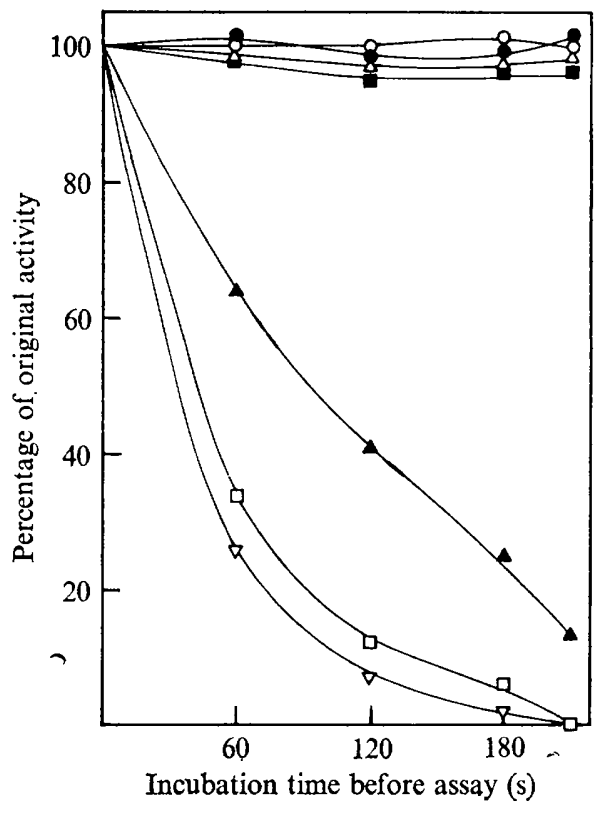

Fig. 2

Fig. I. Effect of trypsin treatment on the thiosulphate-oxidizing activity of various preparations of T. novellus. Preparations ( $2 \mathrm{mg}$ wet wt cells $\mathrm{ml}^{-1}$ or $1.5 \mathrm{mg}$ protein $\mathrm{ml}^{-1}$ in cell-free systems) were treated with trypsin at $25^{\circ} \mathrm{C}$. Samples were assayed immediately after withdrawal. $O$, Whole cells plus $200 \mu \mathrm{g}$ trypsin $\mathrm{ml}^{-1} ; \triangle$, crude extract; $\Delta$, crude extract plus I mg trypsin $\mathrm{ml}^{-1} ; \nabla$, crude extract plus $2 \mathrm{mg}$ trypsin $\mathrm{ml}^{-1} ; 0$, crude extract plus $2 \mathrm{mg}$ trypsin and $3 \mathrm{mg}$ trypsin inhibitor $\mathrm{ml}^{-1}$; $\square$, membrane vesicles; $\square$, membrane vesicles plus I $\mathrm{mg}$ trypsin $\mathrm{ml}^{-1}$; $\rightarrow$, membrane vesicles plus $2 \mathrm{mg}$ trypsin $\mathrm{ml}^{-1} ; \nabla$, membrane vesicles plus $2 \mathrm{mg}$ trypsin and $3 \mathrm{mg}$ trypsin inhibitor $\mathrm{ml}^{-1}$.

Fig. 2. Effect of pronase digestion on the thiosulphate-oxidizing activity of various preparations of $T$. novellus. Preparations ( $2 \mathrm{mg}$ wet wt cells $\mathrm{ml}^{-1}$ or $1.5 \mathrm{mg}$ protein $\mathrm{ml}^{-1}$ in cell-free systems) were treated with pronase at $25^{\circ} \mathrm{C}$. Samples were assayed immediately after withdrawal. $\bigcirc$, Whole cells; D, whole cells plus $200 \mu \mathrm{g}$ pronase $\mathrm{ml}^{-1} ; \Delta$, crude extract; $\Delta$, crude extract plus $100 \mu \mathrm{g}$ pronase $\mathrm{ml}^{-1} ; \square$, crude extract plus $200 \mu \mathrm{g}$ pronase $\mathrm{ml}^{-1} ; \mathbf{n}$, membrane vesicles; $\nabla$, membrane vesicles plus $200 \mu \mathrm{g}$ pronase $\mathrm{ml}^{-1}$.

\section{RESULTS}

\section{Effect of proteolytic enzymes}

Oxidation of thiosulphate by freshly harvested $T$. novellus was not affected by treatment of the cells with the proteolytic enzymes trypsin or pronase (Figs I and 2). Under these conditions, no protein was released from the cells by the proteolytic enzymes (Table I). In contrast, proteolysis of the cell-free extract and the isolated membrane vesicles by either trypsin (Fig. I) or pronase (Fig. 2) decreased the membrane-bound thiosulphateoxidizing activity. A progressive decline of the activity to a plateau was observed with trypsin treatment (Fig. I). In the presence of excess trypsin inhibitor, there was no appreciable loss of activity within the experimental period indicating that trypsin exerted its effect through proteolytic action. The trypsin treatment of membrane vesicles for $30 \mathrm{~min}$ released $50 \%$ of the total protein into the supernatant (soluble) fraction resulting in $70 \%$ loss of activity (Table I).

Treatment of membrane vesicles with pronase decreased thiosulphate-oxidizing activity more rapidly than did trypsin (Fig. 2), resulting in complete loss of activity and $75 \%$ release of protein after 5 min (Table 1 ). The rate of inactivation of the thiosulphate- 
Table 1. Release of protein from whole cells and membrane vesicles by treatment with trypsin or pronase

\begin{tabular}{|c|c|c|c|c|c|}
\hline $\begin{array}{l}\text { Preparations }(2 \mathrm{mg} \\
\text { incubated at } 25^{\circ} \mathrm{C} \\
\text { The trypsin action } \\
\text { assayed for thiosu } \\
\text { activity immediatel } \\
\text { whole cells, or ro5 } \\
\text { and supernatant fra }\end{array}$ & $\begin{array}{l}\text { wt ce } \\
\text { trypsin } \\
\text { stopped } \\
\text { te-oxidiz } \\
\text { ter the } 5 \\
\text { for i } 20 \\
\text { ns. }\end{array}$ & $\begin{array}{l}\text {, or } 1 \cdot 5 \mathrm{~m} \\
\mathrm{ml}^{-1} \text { ) for } 30 \\
\text { ding } 3 \mathrm{mg} \mathrm{so} \\
\text { ivity. Samp } \\
\text { re-incubatior } \\
\text { ith membra }\end{array}$ & $\begin{array}{l}\text { mbrane ve } \\
\text { or with pr } \\
\text { trypsin in } \\
\text { eated wih } \\
\text { er centrifu } \\
\text { icles), prote }\end{array}$ & $\begin{array}{l}\text { rotein } \\
200 \mu \mathrm{g} \\
\text { and sa } \\
\text { e were }\end{array}$ & $\begin{array}{l}\text { were pre- } \\
\text { for } 5 \text { min. } \\
\text { os were then } \\
\text { yed for the } \\
20 \text { min with } \\
\text { in the pellet }\end{array}$ \\
\hline Preparation & $\begin{array}{l}\text { Total } \\
\text { protein } \\
\text { (mg) }\end{array}$ & Treatment & $\begin{array}{c}\mathrm{S}_{2} \mathrm{O}_{3}{ }^{2-} \\
\text { oxidation } \\
(\%)\end{array}$ & $\begin{array}{l}\text { Pellet } \\
\text { protein } \\
\text { (mg) }\end{array}$ & $\begin{array}{c}\text { Supernatant } \\
\text { protein } \\
\text { (mg) }\end{array}$ \\
\hline Whole cells & 0.19 & Trypsin & 100 & 0.19 & 0.00 \\
\hline Whole cells & 0.20 & Pronase & 100 & 0.19 & 0.00 \\
\hline Membrane vesicles & $1 \cdot 5$ & Trypsin & 30 & 0.74 & 0.72 \\
\hline Membrane vesicles & $I \cdot 5$ & Pronase & 0 & 0.36 & $I \cdot I_{2}$ \\
\hline
\end{tabular}

oxidizing activity of membrane vesicles by pronase (Fig. 3) indicated that proteolytic inactivation was a pseudo-first order reaction. These results with the two proteolytic enzymes are understandable on the basis of known differences in their proteolytic specificities (Smyth, 1967).

Thiosulphate had no protective effect on the thiosulphate-oxidizing activity during proteolytic digestion and reduced glutathione (GSH) did not restore the activity in the preparations inactivated by proteolytic enzymes.

\section{Effect of lipase, phospholipases $A, C$ and $D$, and lysozyme}

When whole cells of $T$. novellus were pre-incubated at $25^{\circ} \mathrm{C}$ with lipase, phospholipases A, C or D, or lysozyme, no loss of thiosulphate-oxidizing activity occurred and the cells were not lysed. The thiosulphate-oxidizing activity of membrane vesicles was relatively resistant to lipase, phospholipases $\mathrm{C}$ and $\mathrm{D}$ and lysozyme treatment. However, the activity was more sensitive to phospholipase $A$ and was reduced by nearly $40 \%$ when the membrane vesicles were treated with $100 \mu \mathrm{g}$ phospholipase $\mathrm{A}$ in the presence of $2 \mathrm{mM}-\mathrm{CaCl}_{2}$; the turbidity of the membrane vesicle suspensions was not affected by the treatment.

Phospholipase A is inhibited by EDTA (Zakim, 1970) because of its chelating action on divalent cations. Inactivation of thiosulphate-oxidizing activity by phospholipase A was prevented by EDTA, whereas the omission of $\mathrm{CaCl}_{2}$ alone had no effect. A similar inactivating effect by phospholipase $\mathrm{A}$ was observed with the oxidizing systems of succinate and NADH (Burstein, Kandrach \& Racker, 1971) and with the reversed electron transfer and energy-dependent transhydrogenase systems (Luzikov, Kupriyanov \& Makhlis, 1973) of beef heart sub-mitochondrial particles. Unfortunately, attempts to recover the original thiosulphate-oxidizing activity from the phospholipase A-treated membrane vesicles by incubating with lecithin miscelles were unsuccessful. Such an approach was successful in restoring the activity of several membrane-bound enzymes after treatment with phospholipase A or C (Fleischer et al., 1962; McConnell et al., 1966; Duttera, Byrne \& Ganoza, I968; Martonosi, I968; Martonosi, Donley \& Halpin, 1968). 


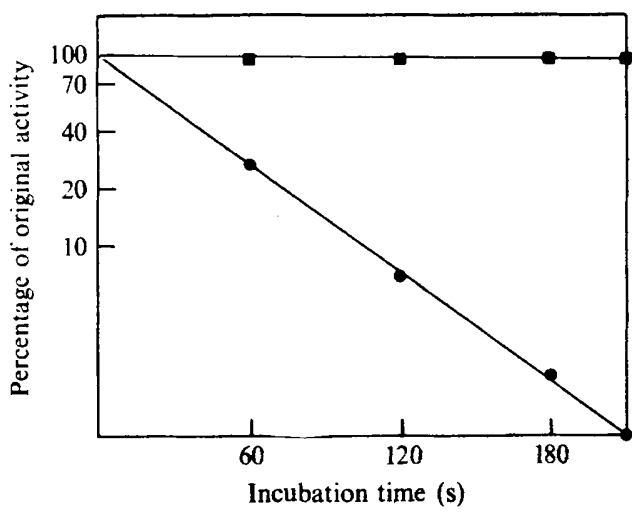

Fig. 3

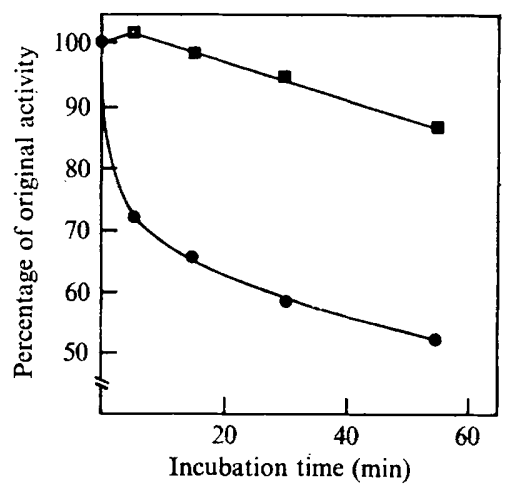

Fig. 4

Fig. 3. Inactivation of the thiosulphate-oxidizing activity of membrane vesicles during pronase digestion. Membrane vesicles (I.5 $\mathrm{mg}$ protein $\mathrm{ml}^{-1}$ ) were incubated at $25^{\circ} \mathrm{C}$ without pronase ( $\square$ ) or with $200 \mu \mathrm{g}$ pronase $\mathrm{ml}^{-1}(0)$ in $0 . \mathrm{I} \mathrm{M}$-Tris acetate/0.02 $\mathrm{M}$-potassium phosphate buffer, $\mathrm{pH} 7.5$. Samples were removed at the times indicated and immediately assayed for thiosulphate-oxidizing activity.

Fig. 4. Effect of lysolecithin on the thiosulphate-oxidizing activity in cell-free extracts. Crude cellfree extract ( $24 \mathrm{mg}$ protein $\mathrm{ml}^{-1}$ ) was incubated without lysolecithin ( $\mathrm{ml}^{-1}(0)$ at $25^{\circ} \mathrm{C}$. Samples were removed at the times indicated and immediately assayed for thiosulphate-oxidizing activity.

\section{Table 2. Effect of detergents on the thiosulphate-oxidizing activities of crude cell-free extracts and isolated membrane vesicles}

Preparations ( $1.5 \mathrm{mg}$ protein $\mathrm{ml}^{-1}$ ) were treated with various detergents at $4{ }^{\circ} \mathrm{C}$ for $30 \mathrm{~min}$ and assayed for thiosulphate-oxidizing activity. After dialysis at $4^{\circ} \mathrm{C}$ for $30 \mathrm{~min}$, there was a considerable loss of activity in the control samples of crude cell-free extracts and membrane vesicles, and so all results are recorded as percentages of the activity of the control sample.

Preparation

Cell-free extract

Membrane vesicles

\section{Treatment}

None

Sodium deoxycholate
Triton X-100

Tween 80

\section{None \\ Sodium deoxycholate}

NT, Not tested.

Activity (\%)

$\overbrace{\begin{array}{c}\text { Before } \\ \text { dialysis }\end{array}}^{\begin{array}{c}\text { After } \\ \text { dialysis }\end{array}}$

\section{Concn}

$(\%)$

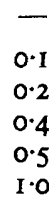

0.1

0.2

0.4

0.5

I. 0

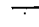

$0 \cdot 1$

0.2

0.4

0.5

I.O

0.5

$1 \cdot 0$

0.5

$1 \cdot 0$

$\begin{array}{rr}100 & 100 \\ 54 & 58 \\ 36 & 43 \\ 12 & 19 \\ 6 & 18 \\ 1 & 7 \\ 100 & 100 \\ 69 & \mathrm{NT} \\ 64 & \mathrm{NT} \\ 44 & \mathrm{NT} \\ 38 & 36 \\ 32 & 41 \\ 100 & 100 \\ 94 & 93 \\ 100 & 100 \\ 94 & 93\end{array}$

100

100

NT

36

$4 \mathrm{I}$

00

93

93 


\section{Effect of detergents}

The effect of ionic and non-ionic detergents on the thiosulphate-oxidizing activity of the cell-free systems was studied before attempting to resolve the membrane-bound complex with any of the detergents. The thiosulphate-oxidizing activities of the crude cell-free extract and isolated membrane vesicles were markedly decreased after treatment with sodium deoxycholate, an ionic detergent, at $0 \cdot \mathrm{I}$ to $\mathrm{I} \cdot 0 \%(\mathrm{w} / \mathrm{v})$ (Table 2$)$. The membrane vesicles were more resistant than the crude extract to the treatment. Dialysis of the deoxycholatetreated preparations did not result in much recovery of the lost activity nor did removal of the detergent by gel filtration through a Sephadex G-25 column. Although these treatments do not guarantee complete removal of deoxycholate bound to the lipoproteins, the results suggested that deoxycholate caused irreversible damage to the thiosulphate-oxidizing system. Sodium deoxycholate is known to disrupt lipid-protein interactions by competing for lipid binding sites on the proteins (Helenius \& Simons, 1975).

Non-ionic detergents, Triton X-I00 and Tween 80 , caused only a small loss of activity in the membrane vesicles (Table 2).

\section{Effect of lysolecithin}

The thiosulphate-oxidizing activity of cell-free extracts was sensitive to treatment with lysolecithin (Fig. 4). Although the degree of inhibition was time-dependent, the activity decreased rapidly to $70 \%$ of the initial level within $5 \mathrm{~min}$ but then declined very slowly. Such treatment did not change the turbidity of the reaction mixture.

Lysolecithin, as a disruptive agent, inhibits respiration and uncouples phosphorylation in mitochondrial electron transport particles (Witter, Morrison \& Shepardson, I957; Honjo \& Ozawa, I968). It is also an effective solubilizing agent for membrane-bound proteins in the mitochondrial inner membrane; small non-vesicular fragments of membrane have been obtained by such treatment of electron transport particles (Komai, Hunter \& Takahashi, 1973; Capaldi, Komai \& Hunter, 1973; Sadler, Hunter \& Haworth, 1974).

\section{Effects of other compounds}

When crude cell-free extracts were pre-incubated with $10 \%(\mathrm{w} / \mathrm{v})$ sucrose for $15 \mathrm{~min}$ at $4{ }^{\circ} \mathrm{C}$, there was a $34 \%$ loss of thiosulphate-oxidizing activity; with $20 \%$ (w/v) sucrose, there was a $49 \%$ loss. Glycerol had a similar effect, causing $50 \%$ loss in activity at $20 \%$ $(\mathrm{w} / \mathrm{v})$ after pre-incubation at $25^{\circ} \mathrm{C}$ for $10 \mathrm{~min}$.

Fractionation of the membrane vesicles between 40 and $90 \%$ of saturation with ammonium sulphate at $4{ }^{\circ} \mathrm{C}$ resulted in complete loss of the thiosulphate-oxidizing activity. Removal of ammonium sulphate by either dialysis or chromatography on Sephadex G-25 did not regenerate the activity, indicating that the inactivation by ammonium sulphate was irreversible.

The thiosulphate-oxidizing activity in isolated membrane vesicles was destroyed by chaotropic anions or dissociating agents; treatment for 10 min at $25{ }^{\circ} \mathrm{C}$ with $0.4 \mathrm{M}-\mathrm{KSCN}$, $0.4 \mathrm{M}$-potassium trichloroacetate, $2 \mathrm{M}$-urea, $2 \mathrm{M}$-guanidine. $\mathrm{HCl}$ or $5 \mathrm{~mm}$-sodium dodecyl sulphate resulted in complete loss of activity. Short-chain alcohols, n-propanol, n-butanol or t-butanol, completely inhibited the thiosulphate-oxidizing activity of membrane vesicles at $0.5 \mathrm{M}$, but methanol and ethanol showed only $30 \%$ inhibition at this concentration. ATP, ADP, AMP, cyclic AMP, FAD, FMN, $\mathrm{NaBH}_{4}, \mathrm{NaF}$, hydrazine sulphate, bovine serum albumin (fraction V), spermine. $\mathrm{HCl}$, spermidine. $\mathrm{HCl}$ and ferricyanide at $0 . \mathrm{I}$ to I $\mathrm{mM}$ had no appreciable effect. 
Table 3. Activities of membrane-bound and soluble rhodanese in

$T$. novellus extracts

Membrane vesicles and the soluble fraction were prepared from $5 \mathrm{ml}$ crude cell-free extract by centrifuging at $105000 \mathrm{~g}$ for $90 \mathrm{~min}$ (Oh \& Suzuki, 1977).

\begin{tabular}{|c|c|c|c|c|}
\hline \multirow[b]{2}{*}{ Preparation } & \multicolumn{2}{|c|}{ Protein } & \multicolumn{2}{|c|}{ Rhodanese activity } \\
\hline & $\begin{array}{l}\text { Total } \\
\text { (mg) }\end{array}$ & $\begin{array}{c}\% \text { of } \\
\text { crude extract }\end{array}$ & $\begin{array}{l}\text { Total }(\mu \mathrm{mol} \\
\left.\text { SCN }^{-} \min ^{-1}\right)\end{array}$ & $\begin{array}{c}\% \text { of } \\
\text { crude extract }\end{array}$ \\
\hline Crude extract & IIO & 100 & 16.8 & 100 \\
\hline Membrane vesicles & $56 \cdot I$ & $5 I \cdot I$ & $7 \cdot \mathrm{I}$ & $42 \cdot 2$ \\
\hline Soluble fraction & $50 \cdot 9$ & $46 \cdot 3$ & $9 \cdot 5$ & 56.5 \\
\hline
\end{tabular}

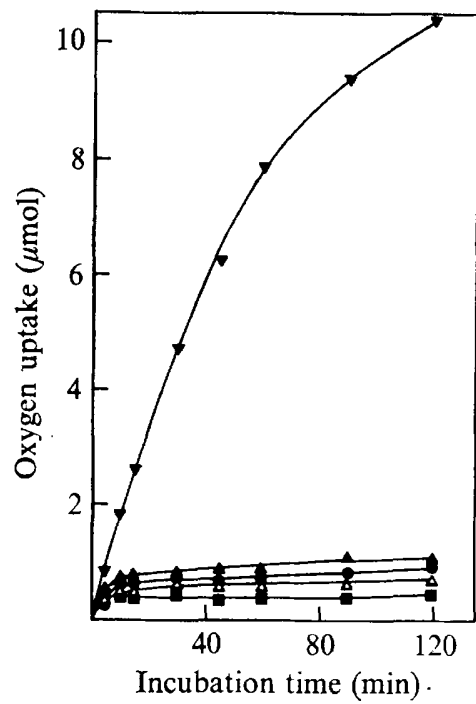

Fig. 5. Release of sulphur-oxidizing enzyme activity from membrane vesicles by treatment with trypsin as in Table I. After centrifuging (105000 g for $120 \mathrm{~min}$ ), the trypsin-treated membrane vesicles were resuspended and assayed for sulphur-oxidizing enzyme activity. $\nabla$, Treated membrane vesicles plus $\mathbf{S}$ and GSH; $\bullet$, treated membrane vesicles plus GSH; $\Delta$, treated membrane vesicles plus $\mathbf{S} ; \boldsymbol{\Lambda}$, untreated membrane vesicles plus $\mathbf{S}$ and $\mathbf{G S H} ; \mathbf{E}, \mathbf{S}$ plus $\mathbf{G S H}$.

\section{Partial resolution of the membrane-associated thiosulphate-oxidizing system}

As described in the preceding paper (Oh \& Suzuki, 1977), the isolated membrane vesicles had activities of cytochrome $c$ oxidase, NADH oxidase (electron transport system) and a membrane-bound rhodanese (Table 3). The activities of the sulphur-oxidizing enzyme and sulphite:cytochrome $c$ oxidoreductase were not detected. Treatment of the membrane vesicles with trypsin released the sulphur-oxidizing enzyme activity from the membranebound enzyme complex system (Fig. 5). Usually, the thiosulphate-oxidizing activity remaining in the membrane vesicles after treatment with trypsin was approximately $30 \%$ of the original activity. The sulphur-oxidizing enzyme, which oxidized elemental sulphur with GSH as cofactor, was isolated and partially purified by Suzuki (1965) from $T$. thiooxidans and by Suzuki \& Silver (1966) from $T$. thioparus. They proposed that the enzyme initially 
Table 4. Release of sulphite-oxidizing activity from isolated membrane vesicles by treatment with sodium deoxycholate

Membrane vesicles were prepared as in Table 3, treated with $0.2 \%(w / v)$ sodium deoxycholate at $4{ }^{\circ} \mathrm{C}$ for $30 \mathrm{~min}$, and dialysed against $0 . \mathrm{I} \mathrm{M}$-Tris acetate $/ 0.02 \mathrm{M}$-potassium phosphate buffer, $\mathrm{pH} 7.5$, for $3 \mathrm{~h}$ at $4^{\circ} \mathrm{C}$ with two changes of buffer. The dialysed preparations were assayed for enzyme activities, which are expressed as $\mu \mathrm{mol} \mathrm{O}_{2}$ consumed $\min ^{-1}$. Cytochrome $c$ (horse heart, type III) was present in preparation D at $50 \mu \mathrm{M}$.

\section{Preparation}

A. Crude extract

B. Isolated membrane vesicles

C. Sodium deoxycholate-treated membrane vesicles

D. C+ cytochrome $c$

$$
\begin{aligned}
& \mathrm{S}_{2} \mathrm{O}_{3}{ }^{2-}- \\
& \text { oxidizing } \\
& \text { activity }
\end{aligned}
$$

$\begin{array}{ll}7.8 & 7.86 \\ 7.6 & 0 \\ 0 & 0.05 \\ 0 & 0.98\end{array}$

Table 5. Isolation of sulphite: cytochrome c oxidoreductase and cytochrome c oxidase from sodium deoxycholate-treated membrane vesicles

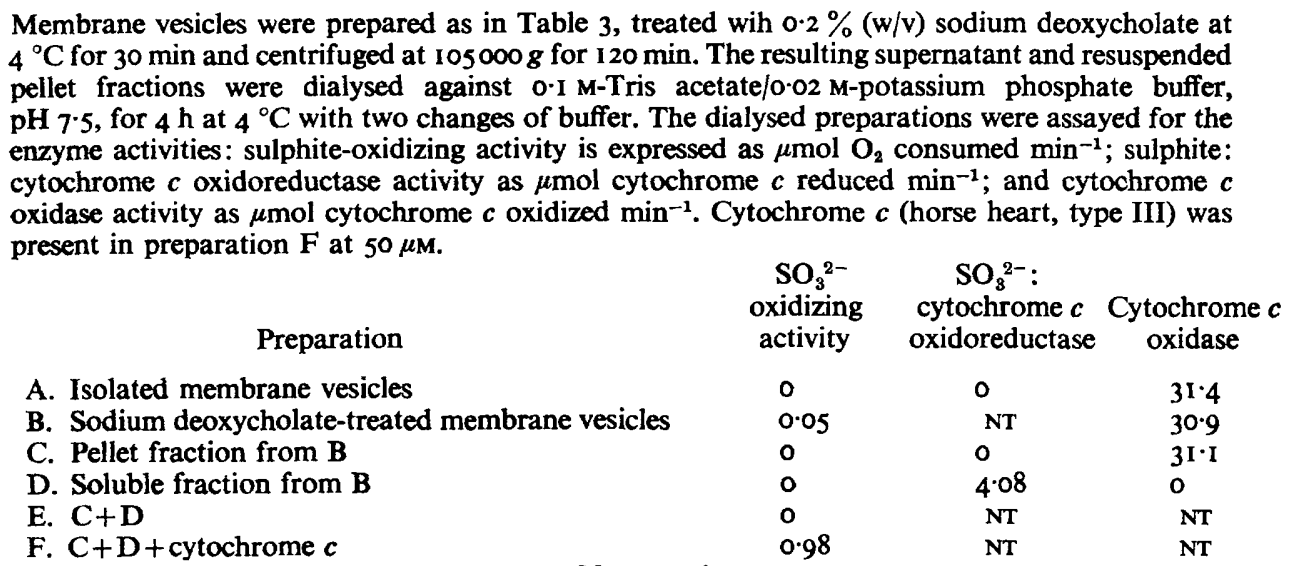
NT, Not tested.

oxidized sulphur to sulphite in the presence of a catalytic amount of GSH followed by a non-enzymic formation of thiosulphate from sulphur and sulphite:

$$
\begin{gathered}
\mathrm{S}+\mathrm{O}_{2}+\mathrm{H}_{2} \mathrm{O} \underset{\text { enzyme }}{\stackrel{\mathrm{GSH}}{\longrightarrow}} \mathrm{SO}_{3}{ }^{2-}+2 \mathrm{H}^{+} \\
\mathrm{S}+\mathrm{SO}_{3}{ }^{2-} \underset{\text { non-enzymic }}{\longrightarrow} \mathrm{S}_{2} \mathrm{O}_{3}{ }^{2-}
\end{gathered}
$$

The same enzyme was also reported in whole cells and cell-free extracts of $T$. novellus, except that the only product was sulphate because the sulphite-oxidizing system of these preparations was very active (Charles \& Suzuki, I966). The sulphur-oxidizing enzyme in the trypsin-treated vesicles oxidized sulphur to thiosulphate in the presence of GSH and the ratio of oxygen consumed to thiosulphate formed was $I: I$, in agreement with the stoicheiometry expected for the proposed mechanism of enzyme action.

When the membrane vesicles were incubated with sodium deoxycholate and then dialysed to remove residual detergent, the treated preparation oxidized sulphite to sulphate in the presence of cytochrome $c$ (Table 4). After high-speed centrifugation, the supernatant solu- 
tion contained sulphite:cytochrome $c$ oxidoreductase activity, while the cytochrome $c$ oxidase activity was in the pellet (Table 5). The sulphite:cytochrome $c$ oxidoreductase activity in the soluble fraction was $13 \%$ of that in the crude extract. The sulphite-oxidizing activity of the combined pellet and soluble fractions plus cytochrome $c$ (preparation $F$ in Table 5) was also about $13 \%$ of that in the crude extract (see Table I in Oh \& Suzuki, 1977). Since the level of cytochrome $c$ oxidase activity in the pellet (Table 5) was identical to that in the crude extract, the above results confirmed the essential role of sulphite:cytochrome $c$ oxidoreductase in the oxidation of sulphite in $T$. novellus.

The methods described above for the release of active sulphur-oxidizing enzyme and sulphite:cytochrome $c$ oxidoreductase from the membrane vesicles were specific for these enzymes and were not interchangeable. These two enzymes were not released in their active forms by treatment with phospholipases $\mathrm{A}, \mathrm{C}$ or $\mathrm{D}$, extensive sonication at $\mathrm{pH} 9.5$, osmotic shock, or extraction with a high salt solution. Chaotropic or dissociating agents (KSCN, guanidine. $\mathrm{HCl}$, urea) or organic solvents (methanol, ethanol, n-propanol, n-butanol, acetone) did not release these enzyme activities. Although the sulphite-oxidizing activity was successfully reconstituted (Table 5), all attempts to reconstitute the thiosulphate-oxidizing activity from the dissociated enzyme components, with or without further addition of partially purified enzymes involved in thiosulphate oxidation (sulphuroxidizing enzyme, rhodanese, sulphite: cytochrome $c$ oxidoreductase, cytochrome $c$ oxidase), were unsuccessful.

\section{DISCUSSION}

The inactivating effect of trypsin, phospholipase A, lysolecithin or sodium deoxycholate on the $T$. novellus thiosulphate-oxidizing activity demonstrated that the membrane complex contained proteins and phospholipids as essential determinants for the overall oxidation of thiosulphate to sulphate.

Of the digestive or dissociating treatments studied, only controlled tryptic digestion successfully released the sulphur-oxidizing enzyme activity from the membrane vesicles, although other treatments might have released the enzyme in inactivated forms. Trumpower, Katki \& Horowitz (1974) reported an enhanced activity of bovine rhodanese by controlled digestion of the enzyme with trypsin. On the other hand, a partially purified sulphur-oxidizing enzyme showed rhodanese activity (Charles \& Suzuki, 1966). Although these observations may be coincidental, it is tempting to suggest that the membrane-associated rhodanese (Table 3), as the thiosulphate-cleaving enzyme, may be closely associated with the sulphuroxidizing enzyme in the membrane vesicles. The close association will be essential in the oxidation of the outer sulphur atom of thiosulphate after cleavage, thus preventing the reassociation of sulphur and sulphite to thiosulphate (Suzuki, 1974).

Although the cytochrome $c$ oxidase activity was recovered entirely in the membrane vesicle preparation (Oh \& Suzuki, 1977), the sulphite:cytochrome $c$ oxidoreductase activity appeared only after deoxycholate treatment of the membrane vesicles. Since trypsin treatment did not release the enzyme, and deoxycholate treatment led to complete clearing of the turbidity of the membrane preparation which suggested that membranes were totally disrupted, the enzyme might have been located well within the membrane vesicle structures. The cytochrome $c$ oxidase and rhodanese were apparently exposed on the membrane vesicles. In the membrane-associated sulphite oxidase of Thiobacillus denitrificans (Aminuddin \& Nicholas, 1974a, b), the enzyme was similarly solubilized by treatment with deoxycholate.

Our results show the presence of all the required enzymes for thiosulphate oxidation in 
the active membrane vesicles. Possible reactions taking place in the membrane complex are:

$$
\begin{aligned}
& \mathrm{R}-\mathrm{SH}+\mathrm{S}-\mathrm{SO}_{3}{ }^{2-} \longrightarrow \mathrm{R}-\mathrm{S}-\mathrm{SH}+\mathrm{SO}_{3}{ }^{2-} \\
& \mathrm{R}-\mathrm{S}-\mathrm{SH}+\mathrm{O}_{2}+\mathrm{H}_{2} \mathrm{O} \longrightarrow \mathrm{R}-\mathrm{SH}+\mathrm{SO}_{3}{ }^{2-}+2 \mathrm{H}^{+} \\
& 2 \mathrm{SO}_{3}{ }^{2-}+4 \text { cytochrome } c\left(\mathrm{Fe}^{3+}\right)+2 \mathrm{H}_{2} \mathrm{O} \longrightarrow 2 \mathrm{SO}_{4}{ }^{2-}+4 \text { cytochrome } c\left(\mathrm{Fe}^{2+}\right)+4 \mathrm{H}^{+} \\
& 4 \text { cytochrome } c\left(\mathrm{Fe}^{2+}\right)+\mathrm{O}_{2}+4 \mathrm{H}^{+} \longrightarrow 4 \text { cytochrome } c\left(\mathrm{Fe}^{3+}\right)+2 \mathrm{H}_{2} \mathrm{O}
\end{aligned}
$$

Sum:

$$
\mathrm{S}-\mathrm{SO}_{3}{ }^{2-}+2 \mathrm{O}_{2}+\mathrm{H}_{2} \mathrm{O} \longrightarrow 2 \mathrm{SO}_{4}{ }^{2-}+2 \mathrm{H}^{+}
$$

in which R-SH is the thiosulphate-cleaving enzyme (rhodanese) and reaction (2) is carried out by the sulphur-oxidizing enzyme. Reactions (3) and (4) are carried out by sulphite: cytochrome $c$ oxidoreductase and cytochrome $c$ oxidase, respectively. In the less active membrane preparations described previously (Oh \& Suzuki, 1977), R-SH is possibly in its oxidized inactive form, R-S-S-R, which is activated either by glutathione (R-S-S-R+ GSH $\rightarrow$ R-SH + G-S-S-R) or by electrons from sulphite and NADH. The latter process may involve the electron transport components present in the membrane vesicles $(\mathrm{Oh} \&$ Suzuki, 1977) which are not directly involved in the reactions shown above, e.g. flavin and cytochrome $b$. Some preparations are activated by GSH, but not by NADH or sulphite for thiosulphate oxidation (Oh \& Suzuki, 1977) possibly because of the physical impairment of the electron transport system.

Further studies on the role of membranes, the nature of the electron transport system, and the energetic aspect of oxidation in the thiosulphate-oxidizing system are required for a better understanding of the mechanism of thiosulphate oxidation in thiobacilli.

This work was supported by grants to I.S. from the National Research Council of Canada.

\section{REFERENCES}

Aminuddin, M. \& Nicholas, D. J. D. (1974a). An AMP-independent sulphite oxidase from Thiobacillus denitrificans : purification and properties. Journal of General Microbiology 82, 103-I 13.

Aminuddin, M. \& Nicholas, D. J. D. (1974b). Electron transfer during sulphide oxidation in Thiobacillus denitrificans. Journal of General Microbiology 82, 11 5-123.

Bursten, C., KANDRACH, A. \& RACKer, E. (197I). Effect of phosphclipases and lipase on submitochondrial particles. Journal of Biological Chemistry 246, 4083-4089.

CaPAldi, R. A., Komal, H. \& HUNTER, D. R. (1973). Isolation of a major hydrophobic protein of the mitochondrial inner membrane. Biochemical and Biophysical Research Communications 55, 655-659.

Charles, A. M. \& SuzUKI, I. (1966). Mechanism of thiosulphate oxidation by Thiobacillus novellus. Biochimica et biophysica acta 128, 510-521.

Dutrera, S. M., Byrne, W. L. \& Ganoza, M. C. (1968). Studies on the phospholipid requirement of glucose 6-phosphatase. Journal of Biological Chemistry 243, 2216-2228.

Fleischer, S., Brierley, G., Klouwen, H. \& Slautterback, D. B. (I962). Studies of the electron transfer system. XIVII. The role of phospholipids in electron transfer. Journal of Biological Chemistry 237, 3264-3272.

Helenius, A. \& Simons, K. (1975). Solubilization of membranes by detergents. Biochimica et biophysica acta 415, 29-79.

Honjo, I. \& Ozawa, K. (1968). Lysolecithin inhibition of mitochondrial metabolism. Biochimica et biophysica acta 162, 624-627.

Komai, H., Hunter, D. R. \& TAKahashi, Y. (1973). Effect of lysolecithin treatment on the structure and functions of the mitochondrial inner membrane. Biochemical and Biophysical Research Communications $53,82-89$.

Lowry, O. H., Rosebrough, N. J., Farr, A. L. \& Randall, R. J. (I95I). Protein measurement with the Folin phenol reagent. Journal of Biological Chemistry 193, 265-275.

Luzikov, V. N., Kupriyanov, V. V. \& Makhlis, T. A. (1973). Studies on stabilization of the oxidative phosphorylation system. III. The effects of substrate and ATP on sensitivity of various energy-linked functions of submitochondrial particles to phospholipase A from Crotalus terrificus venom. Journal of Bioenergetics 4, 521-532. 
MARToNosi, A. (1968). Sarcoplasmic reticulum. IV. Solubilization of microsomal adenosine triphosphatase. Journal of Biological Chemistry 243, 71-91.

Martonosi, A., Donley, J. \& Halpin, R. A. (I968). Sarcoplasmic reticulum. III. The role of phospholipids on the adenosine triphosphatase activity and $\mathrm{Ca}^{2+}$ transport. Journal of Biological Chemistry $243,6 \mathrm{I}-70$.

McConnell, D. G., Tzagoloff, A., Maclennan, D. H. \& Green, D. E. (1966). Studies on the electron transfer system. LXV. Formation of membranes by purified cytochrome oxidase. Journal of Biological Chemistry 241, 2373-2382.

OH, J. K. \& SUZUKI, I. (1977). Isolation and characterization of a membrane-associated thiosulphateoxidizing system of Thiobacillus novellus. Journal of General Microbiology 99, 397-412.

SADLER, M. H., HUNTER, D. R. \& HAWORTH, R. A. (1974). Isolation of an ATP-P, exchangease from lysolecithin-treated electron transport particles. Biochemical and Biophysical Research Communications 59, $804-812$.

SмYTH, D. G. (1967). Techniques in enzymatic hydrolysis. Methods in Enzymology rx, 214-23I.

SUZUKI, I. (1965). Oxidation of elemental sulphur by an enzyme system of Thiobacillus thiooxidans. Biochimica et biophysica acta 104, 359-371.

SuzuKI, I. (1974). Mechanisms of inorganic oxidation and energy coupling. Annual Review of Microbiology 28, 85-IOI.

SuzuKI, I. \& Silver, M. (1966). The initial product and properties of the sulphur-oxidizing enzyme of thiobacilli. Biochimica et biophysica acta I22, 22-33.

Trumpower, B. L., KATKI, A. \& HorowItz, P. (1974). Enhancement of rhodanese activity during controlled digestion with trypsin. Biochemical and Biophysical Research Communications 57, 532-538.

WITter, R. F., MorRISON, A. \& SHEPARDson, G. R. (I957). Effect of lysolecithin on oxidative phosphorylation. Biochimica et biophysica acta 26, I 20-129.

ZAKIM, D. (1970). Regulation of microsomal enzymes by phospholipids. I. The effect of phospholipases and phospholipids on glucose 6-phosphatase. Journal of Biological Chemistry 245, 4953-496I. 